Journal of Management

Vol. XX No. X, Month XXXX 1-29

DOI: $10.1177 / 0149206318759400$

(C) The Author(s) 2018

Reprints and permissions:

sagepub.com/journalsPermissions.nav

\title{
Postacquisition Boundary Spanning: A Relational Perspective on Integration
}

\author{
Helene Loe Colman \\ BI Norwegian Business School \\ Audrey Rouzies \\ University Toulouse Capitole
}

Through a longitudinal, qualitative study, we explore how preexisting embedded relationships shape boundary-spanning actions in the postacquisition integration process. We examine the role of union representatives in the integration process and find that in our case, they are significant boundary spanners. They share knowledge, promote the acquisition, and mitigate conflicts both within and between the merging organizations. Their intra- and interorganizational preacquisition relationships are the contingencies for their boundary-spanning actions. Our study makes several contributions to the literature. First, we show how a set of actors, mostly ignored by the mergers and acquisitions literature, can play a key facilitating role in the integration process. Second, we extend the understanding of the autonomy-integration dilemma in the postacquisition integration literature by conceptualizing preexisting relationships as precursors to postacquisition boundary spanning. Third, we challenge the classical conception of relational inertia as a path-dependent hindrance by showing that preexisting relationships can be leveraged to facilitate postacquisition integration. Finally, we contribute to the boundary-spanning literature by identifying the nature of embedded preacquisition relationships as an important contingency to boundary-spanning actions in interorganizational encounters.

Keywords: mergers and acquisitions; postacquisition integration; boundary spanning; interorganizational relationships; intraorganizational relationships; qualitative methods; union representatives

\footnotetext{
Acknowledgments: We gratefully acknowledge comments and suggestions from Jamal Eddine Azzam, Kevin Corley, Oystein Fjeldstad, Nicola Mirc, Randi Lunnan, and Charles Snow. We thank the two anonymous reviewers and Action Editor Taco Reus for their constructive comments and suggestions. We thank the case company for granting us access to their organization and for partially funding the data gathering.
}

Corresponding author: Helene Loe Colman, Department of Strategy and Entrepreneurship, BI Norwegian Business School, Nydalsveien 37, 0442 Oslo, Norway.

E-mail: helene.l.colman@bi.no 
Postacquisition integration implies the revision of preacquisition organizational boundaries (Drori, Wrzesniewski, \& Ellis, 2013; L.-H. Lin, 2014). It involves the process of dissolving previous organizational boundaries to combine the target and acquiring firms' resources and activities. It is intuitively obvious that boundary spanning is key to postacquisition integration. At its core, postacquisition integration requires two sets of boundary-spanning actions: bridging actions to coordinate activities between the firms and buffering actions to protect the organizations from disruptions (Meznar \& Nigh, 1995). Although few mergers and acquisitions (M\&A) studies explicitly examine the integration process through a boundary-spanning lens (Balogun, Gleadle, Hailey, \& Willmott, 2005), several studies implicitly address actors with boundary-spanning capacities. For instance, we know that target managers perform mobilizing and mitigating actions to create postacquisition value (Graebner, 2004) and that integration managers create value through knowledge transfer in the integration process (Teerikangas, Véry, \& Pisano, 2011). While the extant literature points to boundary-spanning activities performed by managers, we have limited knowledge of the boundary spanning of actors beyond managers or the contingencies for their boundary-spanning actions in postacquisition integration processes.

While exploring a postacquisition integration process in the subsidiary of a multinational company in the mining and metals industry, we unexpectedly discovered that union representatives played a key boundary-spanning role. Contrary to conventional wisdom that union representatives impede change efforts, we found that they were important boundary spanners who fostered integration and mitigated disruptions in the integration process. The union representatives had cooperative preexisting relationships with their union colleagues across the merging organizations and with management and employees within their organization. We observed that these preexisting, embedded relationships provided the conduits for their boundary-spanning actions. These inductive discoveries prompted us to narrow the focus of our study and more specifically, to examine the role of union representatives through the perspectives of boundary spanning and embedded relationships.

Through a longitudinal, qualitative case study of union representatives' role in a postacquisition integration process, we address the following question: How do the preexisting embedded relationships of actors induce boundary-spanning actions and subsequently shape the postacquisition integration process? We claim the following contributions to the literature. First, we show how a set of actors, mostly ignored by the M\&A literature, can play a key facilitating role in the postacquisition integration process given certain contingencies. Second, we contribute to the understanding of the dynamics of postacquisition integration by identifying embedded relationships as the precursors for boundary-spanning actions that facilitate coordination and mitigate disruptions. Third, our findings challenge the classical conception of relational inertia as a path-dependent hindrance. Inert preacquisition relationships between the acquirer and target constitute the building blocks for cooperation and coordination and, thus, represent a previously unspecified integration mechanism. Overall, we move beyond the acquirer-target dyad and show how preexisting embedded relationships play out in the integration process and shape boundary-spanning behavior and, ultimately, the integration outcomes.

\section{Literature Review}

Postacquisition integration is key to harnessing the value creation potential of acquisitions (Haspeslagh \& Jemison, 1991). It involves combining the activities, structures, and 
cultures of the acquiring and target firms in order to exploit the target's capabilities and technologies (Pablo, 1994; Puranam, Singh, \& Zollo, 2006). Integration is a resource demanding and challenging process, and many firms struggle to achieve the desired level and mode of integration (Capron, 1999). In addition, the integration process itself can have disruptive effects on ongoing operations and lead to unintended destruction of the capabilities that motivated the deal (Paruchuri, Nerkar, \& Hambrick, 2006; Ranft \& Lord, 2002). Despite extensive research, our understanding of the dynamics at play in postacquisition integration processes remains limited (Graebner, Heimeriks, Huy, \& Vaara, 2017). Specifically, we lack knowledge of how firms can simultaneously achieve the desired level of integration while preventing disruptions to ongoing operations (Zaheer, Castañer, \& Souder, 2013; Zollo \& Singh, 2004).

A large body of research has addressed the puzzle of postacquisition integration. One stream of research has focused on organizational fit, that is, the extent to which the target's and acquirer's cultures, management styles, and organizational systems are compatible, thus determining the ease with which they can be combined postacquisition (Datta, 1991; Finkelstein \& Haleblian, 2002; Sarala, Junni, Cooper, \& Tarba, 2016). Scholars adopting a process view emphasize the need to focus beyond the fit between the firms and argue that it is the way in which organizational compatibilities play out in the integration process that determines the outcomes of the acquisition, not the organizational fit per se (Haspeslagh \& Jemison, 1991; Jemison \& Sitkin, 1986). Others contend that the overemphasis on the targetacquirer dyad in the literature has limited our understanding of the context of the acquisition. These scholars argue that external relationships, in which the firms are embedded, are key to acquisition outcomes (Anderson, Havila, \& Salmi, 2011).

\section{A Relational Perspective on Postacquisition Integration Process}

A relatively large literature has explored the role of existing relationships as determinants of acquisition behavior. Research shows that alliance networks (Z. Lin, Peng, Yang, \& Sun, 2009), board interlocks (Haunschild, 1993), client ties (Rogan \& Sorenson, 2014), customer and supplier relationships (Öberg \& Holtström, 2006), and information brokers (Sleptsov, Anand, \& Vasudeva, 2013) affect acquisition decisions (Palmer, Xueguang, Barber, \& Soysal, 1995; Porrini, 2004; Zollo \& Reuer, 2010). The role of existing relationships in postacquisition integration, however, has received less attention. This is surprising, as relationships embedded in the social context are characterized by trust, fine-grained information transfer, and joint problem solving and constitute a powerful integration mechanism (Powell, 1990; Uzzi, 1996, 1997).

From research in interorganizational contexts we know that relational capital inherent in embedded relationships promotes interfirm understanding and routines (Elfenbein \& Zenger, 2014; Huang, Luo, Liu, \& Yang, 2016), facilitates knowledge transfer, and reduces communication, coordination, and governance costs (Burt, 1992; Granovetter, 1985). However, embedded relationships may also impede the development of new relationships, as organizational members tend to be inert in the management of their existing relationships and reluctant to develop new relationships (Gargiulo \& Benassi, 2000; Kim, Oh, \& Swaminathan, 2006). Briscoe and Tsai (2011) found that preacquisition interpersonal collaborations help overcome relational inertia and facilitate integration while, surprisingly, decreasing intraunit collaboration. Their findings highlight the complexities of relationships in the integration 
process and underscore the lack of knowledge of how new relationships are formed, and of how existing relationships are maintained, postacquisition.

Postacquisition integration processes may also suffer from the dissolution of existing relationships. Postacquisition integration often implies rationalization, resource reallocation, and organizational changes that compromise the existing relationships within the organizations (Mirc, 2012; Spedale, Van Den Bosch, \& Volberda, 2007). The dissolution of existing relationships may destroy the socially embedded knowledge-based capabilities that motivated the deal, compromising postacquisition capability transfer and value creation (Puranam, Singh, \& Zollo 2003; Ranft \& Lord, 2002). Preserving existing intraorganizational relationships is key to protecting the preacquisition units' strategic capabilities (Zollo \& Singh, 2004).

Postacquisition integration thus involves overcoming the relational inertia inherent in existing relationships to secure integration and value creation from the acquisition while maintaining existing relationships within the merging firms to avoid disruptions to the target's capabilities. New insight into how embedded relationships play out in the integration process may improve our understanding of the long-standing autonomy-integration dilemma in the postacquisition literature (Graebner, 2004; Puranam et al., 2006).

\section{Union Representatives as Boundary Spanners in Postacquisition Integration}

Boundary spanners are individuals who maintain contact with the external environment to translate and diffuse information to internal actors (Friedman \& Podolny, 1992; Leifer \& Delbecq, 1978) and mitigate the tension between the demand for flexibility from the environment and the need for stability within an organization (Wilensky, 1967). In the context of interorganizational relationships, boundary spanners create and shape collaboration (Isbell, 2012) and mediate between the two partner organizations, both facilitating (Tushman \& Scanlan, 1981) and restricting transfer across organizational boundaries (Cross, Nohria, \& Parker, 2002). Their effectiveness depends on their knowledge of the acquisition partner (Balogun et al., 2005) and the strength of ties to the acquisition partner (Tortoriello, Reagans, \& McEvily, 2012). The relationships that boundary spanners are embedded in serve as a base for knowledge transfer and facilitate cooperation and decision-making by acting as a relationship lubricant (Huang et al., 2016). In other words, boundary spanners influence the nature of collaboration and flows between the partners in interorganizational encounters.

Scholars have examined the role of boundary spanners between teams (Ancona \& Caldwell, 1992), between headquarters and subsidiaries in multinational firms (Birkinshaw, Ambos, \& Bouquet, 2017; Schotter \& Beamish, 2011), and between technological domains (Rosenkopf \& Nerkar, 2001). The extant literature has extensively addressed boundary spanning as actions that maintain existing and stable boundaries. In contrast, the postacquisition integration context requires actions geared at transforming or dissolving the preacquisition boundaries (Balogun et al., 2005) and bringing the activities of the two firms within one common organizational boundary (L.-H. Lin, 2014). Our knowledge of how boundary spanning plays out in transitional contexts with malleable boundaries, such as postacquisition integration, is limited.

Union representatives are a set of actors with boundary-spanning potential. From studies on the role of union representatives in organizational change processes we know that they contribute to decision-making processes (Lavelle, Gunnigle, \& McDonnell, 2010) and act as 
a "lubricant" and bridge intraorganizational boundaries between management and employees through their formal roles (Bryson, 2005). However, they also use their power to delay change implementation (Cappellari, Lucifora, \& Piccirilli, 2004). In the specific context of postacquisition integration, the role of union representatives remains largely underexplored. One notable exception is Davy and Scheck (1991), who found that union representatives impede management's change initiatives and are disregarded as key actors in the integration process. Despite these findings, they contend that union representatives constitute important participants in postacquisition integration and that their role in this context warrants the attention of scholars.

In conclusion, the postacquisition integration literature has pointed to the importance of embedded relationships and boundary spanners, yet we lack knowledge of how they shape postacquisition integration processes. Union representatives are an underexplored set of actors with preexisting relationships and boundary-spanning capacities, providing them with the potential to be important actors in the postacquisition integration process. Exploring their role in the integration process may shed light on the tensions and dynamics of postacquisition integration processes (Graebner et al., 2017).

\section{Method}

The aim of our study is to build theory on postacquisition integration through a rich contextual analysis of the integration process "from the perspective of those living it" (Corley, 2015: 601; Maitlis \& Sonenshein, 2010). Qualitative case study research provides unique means for understanding complex social processes and developing new frameworks by using in-depth contextualized insights on a phenomenon (Siggelkow, 2007). Our longitudinal qualitative design with in-depth interviews is thus well suited to understand "how" union representatives shape the integration process.

\section{Research Setting}

In 2008, a French-owned multinational company in the metals and mining industry ("French MNC") acquired a Norwegian family-owned firm ("NewMet"). French MNC had an existing Norwegian subsidiary ("OldMet"), acquired 10 years prior to the focal deal. OldMet consisted of two processing plants for manganese alloys. NewMet consisted of four business units: one processing plant for production of manganese alloys, one processing plant for production of titanium, a trading company, and a power plant. The trading company and the power plant were sold off immediately after the acquisition. The titanium plant was integrated into another division of the French MNC. Thus, the postacquisition integration process examined in this study involves the integration of the NewMet and OldMet manganese plants in the Norwegian subsidiary.

The deal was expected to yield approximately $€ 10$ to $€ 15$ million in operational synergies from cost saving, revenue enhancement, and knowledge sharing. These synergies were planned through optimization of the raw material supply, increased production capacity, improved coordination of the value chain, and cost savings from economies of scale in purchasing and logistics. Extra synergies were expected from the transfer of "best practice" and knowledge between plants. 
NewMet was fully integrated into the existing Norwegian OldMet subsidiary. The three plants remained separate production units with approximately 200 employees each. Production was coordinated at the subsidiary level, and shared support functions were established. The subsidiary management team thus consisted of the CEO, three plant managers, and the functional managers of human resources (HR), finance, R\&D, logistics, and procurement. The OldMet CEO over the past 10 years remained in charge of the Norwegian subsidiary, while the other members of the subsidiary management comprised a balance of ex-OldMet and exNewMet managers.

Norwegian work life has a deeply rooted tradition of employee involvement and is governed by laws and agreements to secure collaboration between employees, unions, and managers (Strand \& Skogseid, 2013). Labor unions exert considerable influence on firm management and are legally entitled to be consulted on issues relating to major structural changes, such as downsizing, outsourcing, and potential mergers (Gooderham, Nordhaug, \& Ringdal, 1999). Employees have, by law, the right to be represented on the board of directors and in the corporate assembly. Employee representatives are elected by and from the workforce, and they have the same rights and obligations as shareholders' representatives.

The predeal negotiations were held between the headquarters of French MNC and the owner of NewMet without the involvement of the union representatives from either of the two firms. However, once the deal was settled, union representatives participated in every stage of the integration process. Approximately $98 \%$ of the employees were members of industry-based unions. The major union affiliation was IndustriEnergi (about $75 \%$ of the unionized employees), a union for employees in the industry and energy sectors. The remaining $25 \%$ of unionized employees were equally distributed between the other unions: Tekna (for technical and scientific personnel), NITO (for engineers and technologists), FLT and Lederne (for engineers and managers), and Negotia (for office workers). Each of the three plants had a total of from four to five union representatives. The senior union representative in each plant was a member of the board of directors as an employee representative. All union representatives were involved in the decision-making processes through their participation in governance organs such as the work environment committee and the corporate assembly. The union representatives were all on plant payroll. The senior union representative in each plant was completely released from his or her ordinary duties in the plant, while the other union representatives were partly released from ordinary duties to carry out their responsibilities in the unions.

We aim to explore how existing relationships shape boundary-spanning actions in postacquisition integration. In our case, union representatives are a set of organizational actors with boundary-spanning potential and preexisting inter- and intraorganizational relationships. By exploring their role, we may gain unique insights into the role of boundary spanning and the influence of existing relationships in postacquisition integration processes. Theory building research relies on revelatory contexts where the dynamics under scrutiny are particularly transparent (Patton, 1990). Our case is particularly revelatory for two reasons. First, the Scandinavian institutional context provides opportunities for union representatives to be important actors. Second, in the metallurgical industry, unions are important in protecting employees' rights, as health and safety issues are critical. Our case offers rich information (Miles \& Huberman, 1994) and makes the role of boundary spanning more "transparently observable" (Pettigrew, 1990). 


\section{Data Collection}

We had access to the Norwegian plants over a 3-year period following the announcement of the deal. This allowed us to trace the unfolding integration process in real time. Real-time data collection mitigates rationalization biases, retrospective sense making, and impression management (Eisenhardt \& Graebner, 2007). We collected data from both the acquirer and the target firms. Our data consist of formal interviews, archival documents, informal conversations, and observations.

Our main data source is the 151 in-depth semistructured interviews conducted in three rounds of data gathering. We conducted 56 interviews in Round 1 (May to July 2009), 49 interviews in Round 2 (November 2009 to February 2010), and 46 interviews in Round 3 (November 2010 to January 2011). In each round of data collection, we interviewed managers, employees, and union representatives in OldMet and NewMet and managers in French MNC. We followed a snowball sampling approach to select informants. We initially interviewed plant managers and main union representatives who in turn suggested other informants to interview. We selected informants who should provide different perspectives to maximize the diversity and depth of viewpoints (Charmaz, 2006). We interviewed the same informants at each round of data collection. Table 1 presents the distribution of interviews.

Our interview guide covered our topics of interest while allowing for exploration of new areas (Charmaz, 2006). The interview guide consisted of open-ended questions to avoid forcing the data and to encourage respondents to account for their experiences. The first phase of interviews focused on the characteristics of the preacquisition organizations, the characteristics of the deal, and respondents' experiences with the integration process so far. The second and third phases focused on the integration process and the consequences of the acquisition. We asked our informants to describe their experiences, their role, and the interaction between unions, management, and employees. We asked follow-up questions and probed for examples to get rich, detailed, and explicit data. Interviews lasted between 45 and 90 minutes and were conducted in the native language of each respondent (either Norwegian or French). All interviews were recorded and transcribed, yielding approximately 2,700 double-spaced pages of transcripts. We conducted the interviews until we reached a point of saturationthat is, until each additional interview added little new information.

The archival data consisted of newsletters and press releases. We analyzed 8 "Integration Newsletters." These were issued during the 1st year postacquisition to inform employees about the progress of the integration process. We also analyzed 14 press releases issued between 9 months preacquisition and 6 months postacquisition. These press releases mostly addressed the financial structure of the deal. In addition, each of the plants issued information letters biweekly to employees; these were analyzed to understand the timeline of events. The archival data complemented our in-depth interviews and helped triangulate our findings. Table 2 synthesizes the different types of data collected and the specific use of each type of data.

After each phase of data collection, we reported our findings to the steering committee that comprised the integration manager, the three plant managers, and the CEO of the Norwegian subsidiary. After the final round of interviews, we reported our findings in meetings with the union representatives. These meetings provided opportunities to discuss our observations with the actors involved and, thus, enhanced the credibility of our findings (Lincoln \& Guba, 1985). 
Table 1

Distribution of Interviews ( $n=151)$ by Company (OldMet, NewMet), Hierarchical Level, and Period

\begin{tabular}{lcccr}
\hline & $\begin{array}{c}\text { Round 1 } \\
\text { Spring-Summer } \\
\text { Company / Hierarchical Level }\end{array}$ & $\begin{array}{c}\text { Round 2 } \\
\text { Fall 2009 to Winter } \\
2010\end{array}$ & $\begin{array}{c}\text { Round 3 } \\
\text { Fall 2010 to Winter } \\
2011\end{array}$ & Total \\
\hline Headquarter managers & 7 & 6 & 7 & 20 \\
OldMet managers & 8 & 5 & 7 & 20 \\
OldMet employees & 6 & 6 & 4 & 16 \\
OldMet union representatives & 9 & 9 & 9 & 27 \\
NewMet managers & 9 & 10 & 9 & 28 \\
NewMet employees & 12 & 5 & 5 & 25 \\
NewMet union representatives & 5 & 49 & 5 & 15 \\
Total & 56 & & 46 & 151 \\
\hline
\end{tabular}

\section{Table 2}

Data Sources and Use

\begin{tabular}{|c|c|c|}
\hline Data Source & Type of Data & Use in the Analysis \\
\hline \multirow[t]{3}{*}{$\begin{array}{l}\text { Interviews ( } 151 \text { in total, } \\
2,700 \text { double-spaced } \\
\text { pages) }\end{array}$} & First phase interviews (56) & $\begin{array}{l}\text { Become familiar with the context, the } \\
\text { industry, and the companies' history, } \\
\text { identity, and culture. Understand production, } \\
\text { the process, and plant operations. }\end{array}$ \\
\hline & Second phase interviews (49) & $\begin{array}{l}\text { Understand informants' perceptions and } \\
\text { experiences of the integration process. } \\
\text { Refine our understanding of the roles of } \\
\text { union representatives. }\end{array}$ \\
\hline & Third phase interviews (46) & $\begin{array}{l}\text { Understand informants' perceptions and } \\
\text { experiences with the integration process. } \\
\text { Refine our understanding of the roles of } \\
\text { union representatives. }\end{array}$ \\
\hline \multirow[t]{2}{*}{ Archival data } & Integration newsletters (8) & $\begin{array}{l}\text { Become familiar with the integration process } \\
\text { plan and the strategic rationale of the deal. } \\
\text { Support and triangulate evidence from the } \\
\text { interviews. }\end{array}$ \\
\hline & Press releases (14) & $\begin{array}{l}\text { Become familiar with the financial structure } \\
\text { of the deal and the governance of the } \\
\text { Norwegian subsidiary. }\end{array}$ \\
\hline \multirow[t]{3}{*}{ Observations } & $\begin{array}{l}\text { Field notes from meeting with the } \\
\text { steering committee }\end{array}$ & $\begin{array}{l}\text { Triangulate evidence from the interviews. } \\
\text { Validate our interpretations. Clarify } \\
\text { uncertainties or misunderstandings. }\end{array}$ \\
\hline & $\begin{array}{l}\text { Informal conversations with } \\
\text { workers, managers, and union } \\
\text { representatives before and after } \\
\text { meetings and interviews }\end{array}$ & $\begin{array}{l}\text { Gain trust from informants, become familiar } \\
\text { with the organizational context, and acquire } \\
\text { the correct technical vocabulary to interact } \\
\text { with workers. }\end{array}$ \\
\hline & $\begin{array}{l}\text { Plant visits (during the first } \\
\text { interview phase) }\end{array}$ & Plant visits (during the first interview phase) \\
\hline
\end{tabular}




\section{Data Analysis}

Following an inductive coding approach (Lincoln \& Guba, 1985), we collected and analyzed data simultaneously. We organized our data (interview transcripts, field notes, and archival data) in Atlas.ti, which allowed us to code and recode, as patterns and themes changed over our analysis. We began by reading and rereading the transcribed interviews and identifying key themes in the data (Van Maanen, 1998). We organized core and recurrent expressions into categories (Coffey \& Atkinson, 1996). These were our informants' expressions describing the roles of the union representatives, the actions of the union representatives and managers, the reactions of the employees, and events in the postacquisition integration phase, Next, we engaged in axial coding, searching for relationships between the emergent categories (Strauss \& Corbin, 1998). Throughout the analysis, we constantly went back and forth between the empirical data and the literature to ground the emerging concepts. Following Dubois and Gadde's (2002) recommendations, we did not force the data into predefined categories; however, when they existed, we used them. For instance, conflict mitigation and mobilizing were salient themes in our informants' narratives. These are concepts developed in the existing M\&A literature (Graebner, 2004).

We identified and specified particular patterns in our informants' stories about the role of union representatives, the existing relationships between management and unions, and the actions performed by the union representatives. As we constructed our narrative, further analysis indicated that the boundary-spanning actions that we had identified addressed two interfaces, intra- and interorganizational. Our longitudinal data then showed how boundaryspanning actions and relationships sustained and changed over time, which eventually led us to our emergent model of postacquisition integration.

\section{Findings}

In this section, we present a detailed account of our findings in a narrative and temporal manner over three phases: preacquisition, initial phase of the integration process $(0-12$ months postacquisition), and later phase of the integration process (12-24 months postacquisition). This "temporal bracketing" (Langley, 1999: 703) into three phases is a way of structuring the description of events that reflects the reality of the integration process. It allows us to examine how the preacquisition relationships and the roles and actions of union representatives evolve over time. We have integrated quotes in the narrative descriptions to exemplify our interpretations. Finally, we summarize our findings and conceptualize the unfolding of the integration process in our emergent model.

\section{Preacquisition Relationships and the Roles of Union Representatives}

Three dominant themes emerged from our analysis of the preacquisition phase. First, union representatives had established cooperative relationships with the union representatives of the acquisition partner plants through their union affiliation. Second, union representatives and management had developed constructive relationships over time. Third, the union representatives' roles were embedded in the institutional context, providing them legitimacy as key actors in strategy development, change implementation, and plant operations. 
Union-union interorganizational relationships. Prior to the announcement of the deal, the union representatives from NewMet and OldMet had extensive interactions. Our informants described how the national union affiliation provided an arena for discussing their shared challenges and advocating their shared interests. These shared interests included regulatory and political issues and concerns about wages and working conditions, industry safety, energy policies and legislation, and health, safety, and environment procedures. A union representative from OldMet described:

Our union has cooperated through many years with the union from the other [NewMet] plants. We are organized in the same union. The union has several committees, and our committee, the electrochemical cooperative committee, consists of 27 or 28 companies with a common set of agreements. Twice a year, we have meetings to further our interests. We have a board that prepares issues, both of a political and more technical manner. . . Then, we have negotiations for our agreements in the electrochemical committee. We have a national meeting as well every 4 years. Then, we meet through conferences arranged by others-for example, conferences around issues such as energy. We work to further the conditions of our industry. (OldMet union representative \#4)

Although the plants were competitors, these arenas promoted cooperation, knowledge transfer, and the development of trusting relationships across the plants.

Union-management collaborative relationships. Union-management collaboration was deeply rooted in the institutional and legal frameworks governing industrial relations and employee participation. Union representatives in both OldMet and NewMet were involved in key decision-making processes as members of the corporate assembly and the board of directors. Our informants emphasized how the institutions provided legitimacy and made the union representatives' participation in decision-making processes and change initiatives inevitable:

The institutions that are core to our cooperative model are the unions, the employers' unions and the government. ... [B]y law we need a corporate assembly with representatives from all the unions, and by law, we need to inform and get feedback there. (OldMet manager \#2)

While the institutions and the union representatives' formal role in the various fora legitimized their role in the decision-making processes in the plants, they also contributed to the development of strong informal norms of participation. The union-management collaboration was embedded in assumptions of "the way things are" and was "taken for granted." One manager described this collaborative relationship:

We have a very good cooperative environment; I am in a management position myself, and that is the way it has been up through the years, as well. We have really good relationships between management and unions. (OldMet manager \#1)

Our informants described extensive, informal, everyday collaborations. For example, union representatives and managers revealed how they regularly and ad hoc dropped by each other's offices to share new ideas on issues such as improvement of operations, safety at work, or new regulations: 
The relationship between the unions and the management is very good. The distance between them and us is short; you just ask whomever you want. There is no need for a formal meeting or anything like that. I feel we are involved and we are kept informed. (NewMet union representative \#3)

Our informants described how the union's goals and objectives were aligned with management's. Union representatives explained that "we [unions and management] agree on the issues we should agree on," such as the strategic direction of the firm, and "we disagree on issues we should not agree on," such as salaries. The ultimate and shared goal for both was the development and survival of the plants. This was confirmed by the employees in the plants:

The unions really try to lead the way and try to make the management initiate collaboration and improvements; the unions are not at all about higher salaries and strikes here. (NewMet employee \#2)

In all the plants, union representatives and management had a history of cooperating during large changes, downsizing, and cost cutting. For example, union representatives and managers had collaborated to develop initiatives to address a dramatic drop in demand for their products. The joint decision to avoid overcapacity and layoffs was to reduce the work hours of all employees by $50 \%$ over a time period of several months. Our informants reported that this decision was based on an open and constructive dialogue between unions and management. Managers underlined that such a decision could not have been reached without the involvement of union representatives. The practice of including union representatives in important changes was perceived by all parties as necessary to secure acceptance from the rest of the organization.

The "managerial role" of union representatives. A dominant theme in our informants' descriptions preacquisition was the "managerial role" of the union representatives. Because of their involvement in strategy and governance organs, union representatives gained access to knowledge and skills that other employees from the shop floor did not have. Through the corporate assembly, they gained in-depth insights into the firm's decision-making processes, strategy development, financial situation, and industry and institutional environment:

Through the corporate assembly, the union representatives have developed business understanding; they are exposed to strategy, accounting and finance, and they need to have an opinion on our different investment projects. So, the corporate assembly is a great arena for developing business understanding. (OldMet manager \#3)

The union representatives thus developed "managerial knowledge" and a comprehensive understanding of the challenges and opportunities of the firm. This knowledge allowed them to be valuable participants in decision-making and in shaping the strategic directions of the plant. They had working communication channels with the employees on the shop floor, allowing them to champion the strategy and future direction of the firm to employees:

It is also natural that we have strategic and business competency, as we are on the board of directors and in the corporate assembly, and this makes taking the message and the strategy out to the organization easier, as well. It goes without saying, this works really well. . . We want to 
be solution oriented and make an effort to be number 1 in the future ...; we want to be the firm that survives, both in the short and long term. (OldMet union representative \#4)

The union representatives described themselves as "informal managers" and as top management's "peers." The shop floor workers acknowledged that the union representatives' formal role was first and foremost to advocate for the workers' interest. However, they echoed management's perception of the union representatives" "managerial role":

The unions are just as good for the plant as for the workers. This way, management doesn't need to deal with the 200 of us. The unions here are not only occupied with fights for salaries and strikes ... . ; for example, now, they are very involved in making improvements to the plants. (NewMet employee \#1)

The union representatives also brought important insights and perspectives from the shop floor into the discussions in the corporate assembly and challenged management's views on strategic issues. In this way, union representatives' participation in the corporate assembly was appreciated by the top managers:

For me, the corporate assembly was as important as my management team. The management team will agree with you no matter what. From the corporate assembly, we got diverging viewpoints from all parts of the organization. They [union representatives] have a lot of knowledge about what is going on in the plant. (OldMet manager \#6)

Table 3 provides additional quotes for pre-existing relationships and union representatives' roles prior to the acquisition and details the first-order findings and key themes.

\section{Initial Phase of the Integration Process: Sustained Relationships and Union Representatives' Boundary-Spanning Actions}

During the first 12 months after the deal was completed, ongoing activities included integrating information technology systems, supply chain activities, and purchasing and logistics. We observed that the collaborative relationships between management and union representatives were sustained as the integration process unfolded. Furthermore, the union representatives spanned the boundaries between the hierarchical levels of the firm by performing mobilizing actions in the integration process. They also bridged the target and acquiring firm boundaries through their sustained relationships. Finally, the union representatives promoted the acquisition both inside their own firms and across the firms.

Sustained union-management collaborative relationships. The interaction between management and union representatives in this phase was in line with the established norms of involvement and participation that had characterized their interactions prior to the acquisition. The union representatives attributed the continued constructive cooperation to their preacquisition status as legitimate representatives for employees and legitimate partners for management. In the same vein, managers emphasized how the cooperative relationships continued into the integration process. As noted by an OldMet manager (\#4), "We have had success forming cooperative relationships with the unions [in the integration process]." 
Table 3

\section{Preexisting Relationships and Union Representatives' Roles Prior to the Acquisition}

First-Order Findings and Representative Quotes

Key Themes

Union representatives work as bridges between the plants through formalized meeting arenas:

"We met in the different types of forums; we were all in the same union and met in the cooperative forums." (NewMet union representative \#4)

Their union networks provide access to knowledge to further union interests:

"We had a very good cooperation prior to the acquisition. We had a lot of interests in common. Tariffs and energy issues for example." (NewMet union representative \#1)

Union and management have informal and open relationships:

"Management plays with an open hand. Our collaborative forums work really well. Information flows freely." (OldMet union representative \#1)

"I am organized in the union, so is everyone else, and there is a good tone between the unions and management, really open, everyone says what they mean." (OldMet employee \#3)

"We have good communication with management. We can talk to them. ... We are included and have influence on our workplace, and our opinions are heard." (OldMet union representative \#3)

"We have a lot of leeway here for different opinions (between management and union representatives)." (OldMet manager \#4)

Unions representatives work as management's collaborative partner:

"The relationships between the unions and the management, they have a good tone . . ; they follow the rules and regulations for cooperation. Sometimes, I feel management actually takes whatever the unions say too much into consideration." (NewMet employee \#3)

"The unions here and the management have a good relationship. I do sense a lack of push from the unions sometimes . . . ; we've done really well, but they still didn't push for an increase in wages. I mean . . . we are well paid, but still.” (OldMet employee \#2)

Union representatives as legitimate and knowledgeable actors:

"By Norwegian law, the unions have to be represented in the boards and management of the organization. By law, we have to negotiate and get access to numbers, accounting information, investments, etc. We see the numbers, and we know the game. We want to move in the same direction as management." (NewMet union representative \#2)

"Our main contribution to the productive and effective plants is our competency. Our level of competency is very high. We have high technical skills among the operators. And since our management acknowledges this competency - well, this provides for a good cooperative climate." (OldMet union representative \#4)

"As an employee here for 28 years, I have a lot of influence both up and down, and I am used to people listening to me." (NewMet union representative \#5)

Union representatives' decision-making role:

"In the corporate assembly, we have group work; management doesn't make a decision and then inform the unions; we involve them early, and we don't just inform them of decisions; they are part of them." (NewMet manager \#5)

"For several years, we have been working like that-management dares to use the unions in different situations, because we are a part of management, so to speak. We are managers for our members, but they dare to include us [in decisions]." (OldMet union representative \#5)

Union representatives as strategic champions:

"To contribute to the development of the company, that is our main task. My role vis-àvis management is to test ideas and then reach an agreement and then take that out to the rest of the organization." (NewMet union representative \#2)

"We have contributed to change and downsizing initiatives, but that is because we know that the foundation of these changes is that there are no layoffs, only people leaving because of retirement or because they resign and packages - that way, people are happy and find something else to do." (OldMet union representative \#4)

Union-management
collaborative relationships

The "managerial" role of union representatives 
The union representatives in the Norwegian plants were not involved in the acquisition decision, as this decision was made in the French MNC. However, after the announcement of the deal, they were informed about the strategic rationale of the acquisition and involved in developing the acquisition integration strategy. Both OldMet and NewMet union representatives were generally positive toward the deal:

We [the union representatives and management] use each other for what it is worth. And this is the way it is with the acquisition, as well. We knew the whole time what was going to happen, and we supported the company from day 1 . We saw that the acquisition was a smart move. (OldMet union representative \#3)

Union representatives perceived the strategy behind the deal and the explicit goals of the acquisition to be in line with the firms' strategy. They perceived the acquisition as a means to secure their survival in the face of growing international competition. Furthermore, union representatives considered their involvement and their collaborative relationships with management to be critical in this phase of the integration process:

We are part of management. We are leaders for our members. Management includes us; we do not have decisions imposed upon us. Now, when we are entering the "French MNC" system, we are really put to the test, and there are plenty of challenges up ahead. If we hadn't had this background, things would have gone bad a long time ago. (NewMet union representative \#4)

The mobilizing actions of union representatives. Three types of mobilizing boundaryspanning actions emerged as dominant themes in our data. First, union representatives acted as "sparring partners" for managers:

Being a union representative, I have been informed about the merger between OldMet and NewMet, and all the different unions have been involved to give advice regarding how to perform a successful integration. (NewMet union representative \#2)

Our CEO has had lots of good thoughts on organizing of the plant, and he often makes a phone call: this is what I've thought—what do you think? (OldMet union representative \#4)

They gave advice based on their business knowledge, their understanding of the strategic rationale of the deal, and their tight connection with the employees on the shop floor. They therefore provided management with an alternative perspective on the acquisition implementation:

Management uses us as a ... well, call it a guideline — they see that they are aligned with us ... that what they do is according to our thoughts and ideas. (OldMet union representative \#4)

The union representatives participated in workshops established to realize synergies from the deal and improve the coordination and the performance of primary activities. They provided their insights and suggestions on the optimization of the raw material supply, the coordination of the value chain, the implementation of coshipment, the reorganization of distribution, and the reduction of the number of warehouses. For example, union representatives were involved in planning and implementing the transfer of silico-manganese production from one of the OldMet plants to the NewMet plant. 
Managers disclosed how they considered union representatives as their sparring partners. Managers and union representatives shared the responsibilities of maneuvering the plants through challenging and uncertain situations while having insufficient access to information:

We definitely do not agree on everything with the unions, and I think they probably don't feel sufficiently informed about the integration process, but neither are we in management - there are a lot of uncertainties at this point. But, we cooperate, and the unions contribute by taking more than their share of responsibilities to make this work. (NewMet manager \#4)

Both managers and union representatives underlined that this sparring partner relationship was not "without bumps in the road." They described minor disputes and disagreements related to both strategic and implementation issues. One example of a disagreement, which emphasizes the sparring partner relationship, was voiced by OldMet union representatives:

We have had some discussions with management about the price we paid for NewMet. Because everything wasn't all bliss over there (in NewMet), as we seemed to think. We probably paid too much for them. (OldMet union representative \#4)

Second, union representatives took on the role of "information brokers" between employees and management to share information across the organization. They had access to managerial information from their participation in the firm's decision-making processes and a channel to all the employees through their meetings with the union members. Most employees were not directly involved in the integration process; however, virtually all of them were union members, and the union meetings were important channels for access to information about the integration process:

I haven't really been involved in the acquisition or the integration process. But, I have the information I need about what's going on. We've had regular meetings with our union throughout the process. (OldMet employee \#4)

For example, union representatives presented the decisions and initiatives from the synergy workshops to the employees, detailing the consequences of change initiatives for the day-to-day activities of the employees. Employees described that the information provided by the union representatives complemented the information from formal communication channels, such as the integration letters and information meetings held by the Norwegian subsidiary's CEO.

Third, union representatives acted as "change implementers" by facilitating the implementation of integration initiatives. For example, they took part in selecting employees to participate in and contribute to the different integration activities. They used their influence to muster commitment and positive attitudes among the employees on the shop floor. In this phase, the integration process was an important topic on the agenda in the corporate assembly and other formal and informal meeting arenas. The managers described how they discussed and collaborated with the union representatives regarding how to implement the necessary changes and how the union representatives were crucial in communicating decisions to the shop floor and operationalizing the changes: 
We have involved the corporate assembly and had working meetings with the union representatives, the 5 main union representatives. The union representatives have then come up with the plan to move this forward by involving other employees. (NewMet manager \#3)

Managers acknowledged the importance of the union representatives in the process of cascading information down to the shop floor, thus crossing intraorganizational boundaries and getting all the employees "on board":

We see now that the unions are pulling the workers with them in the process, and for us, it is not a question about whether to involve the unions or not; they are a natural part of the process. We have confidence in them in the process. ... If you are running an initiative, it doesn't help if the people who are involved, those who have to change, are not part of it. (NewMet manager \#2)

Sustained union-union interorganizational relations and union representatives' bridging actions. Immediately after the announcement of the deal, before formal communication lines between OldMet and NewMet were established, union representatives spanned organizational boundaries and performed "bridging actions." They contacted their union colleagues in the other plants to gather information about the acquisition, the partner plants, and the new owner. NewMet union representatives described how they actively approached their union colleagues in OldMet in search of information about their new owner and how OldMet union representatives reached out to them:

As soon as we heard that we were bought, I got a phone call from the union representatives from OldMet. So, we knew each other really well. So, as soon as the acquisition was announced, we got together to plan how we were to cooperate- how to merge our agreements, how to bargain together, how the unions were to stand together facing the corporation. (NewMet union representative \#2)

Through their union affiliation, the union representatives had developed trusting relationships across the plants preacquisition. Preacquisition, their relationships were the conduits for union-specific information and industrial relations issues. Postacquisition, however, their interactions soon became geared toward becoming one firm. Through ongoing communication between the unions, NewMet union representatives received credible information about the French MNC and the acquisition from the OldMet union representatives. Likewise, OldMet union representatives received information about NewMet. This allowed the union representatives to interpret and make sense of integration issues and prevented potential concerns from escalating into negative attitudes towards the deal and the acquisition partner.

They also shared information about the peculiarities of each plant and the potential sources of learning between the plants. Union representatives shared knowledge on operational issues to improve the implementation of practical synergies, for example, how to optimize the supply of raw material or the coordination of primary activities in the value chain. In addition, the union representatives discussed and planned how to perform their union functions in the merged firm.

The promoting actions of union representatives. The union representatives promoted the acquisition both to the union representatives of the acquisition partner (interorganizational promotion) and to the employees in their respective plants (intraorganizational promotion). 
Immediately after they received the news of the acquisition, the union representatives from OldMet began promoting the deal and the French MNC to NewMet union representatives. They emphasized how they believed the acquisition was an opportunity for both firms and expressed their experiences with French MNC as a solid, trustworthy owner:

When the MNC bought us years ago, we were threatened by closure. Our previous owner had other plans for us, so the MNC was our savior. Ever since our business has been doing well, it has been easy to have them as an owner, and they have invested in the plants. . . . The union representatives in NewMet are skeptical; they do not know what they are coming to. So, that is our challenge, to integrate them in a positive manner. We have told them over and over that the French MNC is a very good owner. (OldMet union representative \#3)

In the same manner, the NewMet union representatives described that the OldMet union representatives encouraged and promoted the new owner to them:

I assumed that everything would remain the same, only that we'd get new owners. I knew that OldMet was our main competitor and that they already had two plants here. And I know the union people there, I called them, and they assured me that this was a good thing. (NewMet union representative \#2)

Union representatives from both NewMet and OldMet described how they "sold the acquisition" to employees in their respective plants and undercommunicated the potential downsides. They emphasized how the deal was beneficial to the plants and how management was making the right decisions regarding the deal and integration process:

Our most important task vis-à-vis the organization is to hold meetings for our members here at the plant to tell them what is going on. We told them how the MNC was buying a new production unit to get better control over the flow of materials here in Norway. And I said that I thought that was a smart move to strengthen our competitive position. I didn't really have to work very hard to convince my organization that this was a good move. (OldMet union representative \#4)

The employees corroborated the union representatives' account of the communication between union representatives and shop floor workers:

It seems like OldMet knows what they're doing. That is the picture I get from [the unions]. I don't have that much information about the deal, but that is the impression I have gotten-I can't say I've heard anything negative about the acquisition. (OldMet employee \#5)

The communication between unions and employees was particularly salient in the descriptions from NewMet informants. The NewMet union representatives expressed that involving the employees at all levels was critical for the outcomes of the deal and for the future of the firm. They reported that they shared information about the French MNC, the Norwegian subsidiary, and the acquisition with the NewMet employees.

Through the communication both between the union representatives from the different plants and between union representatives and employees within the plants, the positive view of the acquisition was shared between plants and broadcast within each plant. Table 4 provides additional quotes for union representatives' boundary-spanning roles in the early phase of the integration process and details the first-order findings and key themes. 
Table 4

\section{Union Representatives' Actions and Collaboration in the Early Postacquisition Phase (0-12 Months After Deal Completion)}

First-Order Findings and Representative Quotes

Continued open and constructive relationships between unions and management: "The union representatives have not been formally involved in the decision process. . .. We are involved where we should be involved, and the integration is a post on the agenda every meeting in the collaborative forum." (NewMet union representative \#4)

Positive reactions of union representatives toward the acquisition and the integration process:

"All the unions want to contribute to a good merger, and we are looking forward to taking part in the design of a new manganese giant." (NewMet union representative \#4)

"When the integration process began, we found it very exciting to explore how another organization is working to achieve similar goals, and we are looking forward to seeing the result of the work from all different synergy groups." (OldMet union representative \#4)

The union representatives are "sparring partners for managers":

"Our managers ask for advice, and we are sparring partners to make sure that what management brings forth is rooted in reality and is supported by us [the unions]." (OldMet union representative \#3)

"All the unions in OldMet gave common advice to the steering committee of the integration, and we can see that this already has given some results." (OldMet union representative \#4)

The union representatives as change implementers and information brokers:

"We have cooperated with the unions . . ; in a process like this, you can't just move some managers around and expect that that will do it. You have to make sure the whole organization is with you - and for that you need the unions." (NewMet manager \#5)

"We think that thorough information, open-mindedness and broad involvement are very important. Information is important in order to avoid uncertainty, give the same understanding to everybody and create focus on the positive potential. Another key for success is everyone's ability to learn from colleagues in a humble way. It is important for all of us to understand that we are equally valuable and that our future competitiveness depends on how well we cooperate - at all levels." (OldMet union representative \#4 early in the integration)

Union representatives initiating contacts across the plants:

"I have always had contact with the other plants through my involvement in the unions. I have always had contact with them, . . . but after the acquisition, there is more contact.” (New Met union representative \#5)

"The unions were involved, and from where I am standing, it seems like they were coordinated across the plants." (OldMet employee \#1)

"We have been in the 'French MNC' system for a while and have told them about our experiences . . . , but we have not had formalized meetings." (OldMet union representative $\# 2$ )

"The advantage was when the company started arranging board meetings for all the plants, we knew each other. It was way easier to have discussions in the meetings, because we trusted each other across the plants." (OldMet union representative \#3)

"I know the union people [in OldMet], so I called them. They told me [the acquisition] was really a good opportunity." (NewMet union representative \#2)

"We [union representatives from the different plants] have met on several occasions. We are on the electrochemical cooperation committee. When the acquisition was announced, we contacted them, and we've had informal contact ever since, parallel to the integration process." (OldMet union representative \#3)
Key Themes

Union-management sustained collaborative relationships

The mobilizing actions of union representatives

The interorganizational bridging actions of union representatives 
Table 4 (continued)

First-Order Findings and Representative Quotes

Key Themes

Union representatives sharing knowledge between the plants:

"Before the acquisition, a lot of issues were confidential, so we kept some issues to ourselves; after the acquisition was announced, we could share everything."

(NewMet union representative \#4)

"Right away, we started thinking about how to act as a unit [the union representatives from the different plants] — how to integrate our agreements, how we could negotiate together for salaries, how to make the different unions act as one." (NewMet union representative \#2)

"We [the union representatives from the different firms] didn't talk much about work [before the acquisition], because we were competitors. And we had an agreement that what they did they kept to themselves and vice versa. When the acquisition happened, then we started sharing [operational] information - then everything was different." (OldMet union representative \#1)

Promoting the acquisition to their union colleagues in the other plants:

"We are constantly on the phone with the unions in NewMet. Last time, we went through OldMet's history with them and told them about our relationship with the French MNC." (OldMet union representative \#4)

"When we were down there, I and the union representative from NewMet went through French MNC history and told them [the employees] about the cooperation the plants have with them, and we had nothing negative about them, because things have been good." (OldMet union representative \#2)

"The people in the NewMet firm had more questions than us. We knew the French MNC well. So, we tried to make the acquisition less threatening; we tried to defuse the deal. The French MNC is not a big bad wolf, out to harm the plants. And, I think us doing this contributed to the integration process moving along easily." (OldMet union representative \#2)

Promoting the acquisition to the employees in their plants:

"The merger, it is good for OldMet. We have been told this [from the unions]. They are our competitor; we were compared to them before, and they have always been more efficient than us. It all seems very reasonable." (OldMet employee \#1)

\section{Later Phase of the Integration Process: Sustained Relationships and Union Representatives' Boundary-Spanning Actions}

In this phase, 12 to 24 months after deal completion, operational integration activities were carried out. Synergies related to primary activities, such as optimization of the raw material supply and production coordination, were implemented. The integration process was now geared toward the coordination of support activities between the three plants, such as HR and R\&D. The existing relationships between the unions, and between management and unions, were sustained. The sustenance of these relationships facilitated knowledge sharing both between and within the plants. Furthermore, we observed that the union representatives were engaged in the boundary-spanning activities of facilitating day-to-day operations within the plants to prevent disruptions and to mitigate conflicts between plants.

Sustained relationships. As in the early stage of the integration process, the collaboration between the union representatives and management continued in an informal and ad hoc manner. Their discussions were reciprocal exchanges of information and provided a testing ground for ideas: 
The union representative, when he gets mail he drops by for a cup of coffee, I then try to sow some seeds, to get him warmed up and test things ..., and I think he does the same with me. We have a lot of leeway here for different opinions. (OldMet manager \#4)

The union-union relationships also sustained throughout the integration process. In this phase, the knowledge transferred between the union representatives of NewMet and OldMet focused on coordination of long-term support activities. Union representatives collaborated across plants to contribute to the organization of procurement, HR, and R\&D in the merged firm. For example, they were involved in coordination of R\&D policies between plants at the Norwegian level. They were also involved in the creation of a joint HR program for competency development and succession planning. The intention was to facilitate worker mobility both within the Norwegian subsidiary and across the entire MNC. The content of the relationships thus shifted from concerns about the acquisition to concerns about the operational functioning of the merged firm.

The mitigating actions of union representatives. Dominant themes in our data in this phase of the integration process were the actions performed by union representatives to ease employee concerns and mitigate conflicts between plants. The union representatives' conflict mitigation roles spanned both internal boundaries between employees and management and the boundaries between the preacquisition units. In this phase, employees on the shop floor showed some unrest. They were concerned about the higher levels of operational and integration-related activities causing increased workloads. In an effort to ease frustrations, the union representatives reported that they explained to employees that the increased workloads would be temporary. The union representatives worked to "calm down" employees and urged them to stay positive and patient:

I made a complaint the other day [about the added workload with integration activities], and then, the union representative came to me and urged me not to complain. (NewMet employee \#1)

R\&D and HR coordination took longer to implement than initially planned. This delay in the implementation of changes elicited employee unrest and concerns regarding future changes. As the union representatives were involved in integration decision-making, they were able to provide detailed information about the anticipated changes in terms of R\&D or HR:

We saw that conflicts were emerging. We had some really good agreements here that they didn't have in the other plants. ... I have tried to calm our members here and tell them that we can't be on the frontiers fighting for everything. (OldMet union representative \#4)

The union representatives kept emphasizing the positive aspects of the acquisition and the benefits of the acquisition for the plants, as they had done earlier in promoting the acquisition. Their conflict mitigation was acknowledged and appreciated by managers:

The cooperation with the unions is good, and they have taken their share of responsibilities [for mitigating disruptions] in the organization. (NewMet manager \#6)

As the integration process evolved, and as more cooperation and interaction were necessary between plants, union representatives also took on the role of mitigating conflicts 
Table 5

Union Representatives' Boundary-Spanning Actions in the Later Integration Phase (12-24 Months After Deal Completion)

\begin{tabular}{|c|c|}
\hline First-Order Findings and Representative Quotes & Key Themes \\
\hline $\begin{array}{l}\text { Calming employees to prevent disruptions: } \\
\text { "I have avoided focusing on the other stuff [the negative issues in the integration } \\
\text { process] because that would only make more unrest." (NewMet union representative } \\
\text { \#2 about communication with NewMet employees) } \\
\text { "When new things are to be implemented . . or, for example, what is happening in this } \\
\text { acquisition, we go in and calm the employees, tell them that we are going to keep our } \\
\text { agreements; we are going to make sure that this turns out well [in terms of workers' } \\
\text { rights]. So, we work to put out fires in the organization-and that is because we do } \\
\text { know what is going on." (OldMet union representative \#3) } \\
\text { "I was talking to [name of union representative] and made a comment of how slow } \\
\text { things were going [with the integration activities] and how we could speed things up, } \\
\text { and then, he sort of just told me to take it easy." (NewMet employee \#2) }\end{array}$ & $\begin{array}{l}\text { The mitigating } \\
\text { actions of union } \\
\text { representatives }\end{array}$ \\
\hline $\begin{array}{l}\text { Mitigating conflicts between the plants: } \\
\text { "I make sure we have contact with the other plants so that we avoid a competitive } \\
\text { attitude. . . So, we have to smooth over so that we avoid competition between the } \\
\text { plants." (OldMet union representative \#4) }\end{array}$ & \\
\hline
\end{tabular}

between plants. Although few conflicts between the plants were reported, some competitive attitudes arose between them. OldMet and NewMet employees readily acknowledged the benefits of "becoming one" and "becoming stronger," such as gaining negotiation power toward suppliers. However, they perceived increased competition for financial resources for heavy investments from the headquarters of the MNC in Paris postacquisition. NewMet was a family-owned company prior to the acquisition, and employees were not used to having to compete for resources with other plants and were unaccustomed to the politics of negotiating and lobbying for resources from the headquarters. The union representatives emphasized how they were able to quell competition and limit conflicts that could have impeded the finalization of the integration process:

There were some conflicts between the plants... . [W]e have used a lot of time trying to make up. The union representative at the other OldMet plant and I went down to NewMet and had a good talk with the union representatives there. ... [W] got to know one another, and we know where the other party stands. ... [W] e made them understand that being part of OldMet is not a bad thing. (OldMet union representative \#3)

In sum, union representatives' boundary-spanning actions in this phase were geared toward both intra- and interorganizational conflict management. Table 5 provides additional quotes for union representatives' boundary-spanning roles in the later phase of the integration process and details the first-order findings and key themes.

\section{Emergent Model: A Relational Perspective on Postacquisition Integration}

In the previous sections, we reported a narrative description of the integration process, reflecting our informants' interpretations. In this section, we propose an inductive model that 
Figure 1

A Relational Perspective on Postacquisition Integration

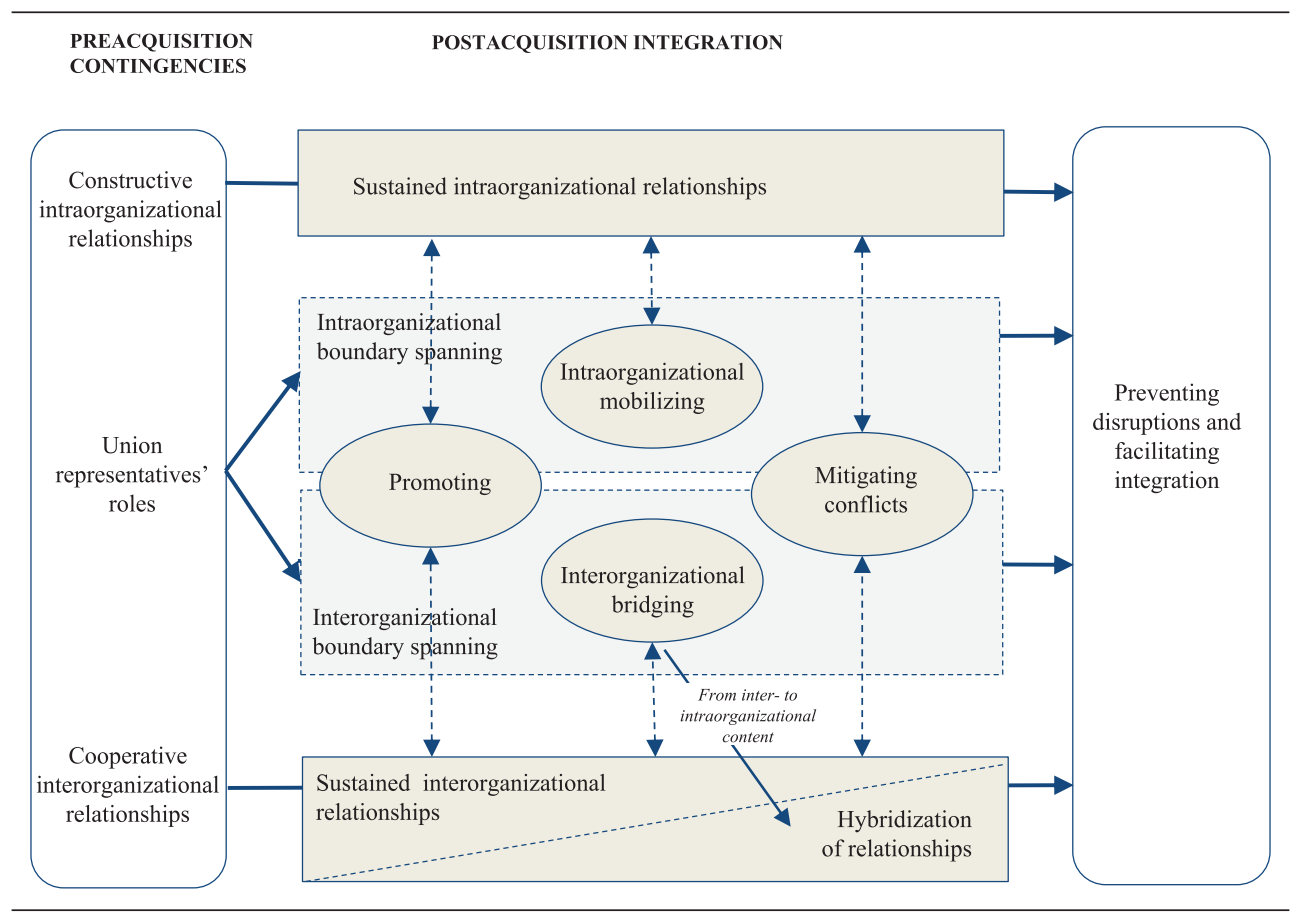

shows the dynamics between the preacquisition roles and relationships of union representatives and their postacquisition boundary-spanning actions (see Figure 1).

We found that in our case, union representatives were important boundary spanners in the postacquisition process. In line with existing literature, we defined their mitigating, mobilizing, promoting, and bridging actions as boundary spanning (Balogun et al., 2005; Friedman \& Podolny, 1992; Marrone, 2010). These boundary-spanning actions prevented potential disruptions in the organization and fueled the coordination between the two organizations, making the union representatives key actors in the integration process.

We found that the union representatives performed boundary-spanning actions across both intra- and interorganizational boundaries. First, the union representatives worked at the boundaries of the hierarchy within the organization. They promoted the acquisition to employees, they mobilized toward further integration, and they mitigated conflicts between management and employees. Second, working at the boundaries between the acquirer and target, the union representatives promoted the acquisition to the partner plants, worked to bridge the target and acquiring firm, and mitigated conflicts between the plants. Thus, they worked within the boundaries of their own organization by buffering and protecting the organization from the disruptions of the integration while working across the organizational boundaries by bridging between their own organization and the acquisition partner (Meznar \& Nigh, 1995).

We observed that the union representatives' boundary-spanning actions were contingent on their roles and their embedded relationships. First, through their roles, they had the knowledge, 
legitimacy, and "managerial" capabilities necessary to perform boundary-spanning actions. Second, union representatives had the "conduits" for performing boundary-spanning actions through their preexisting and enduring relationships. Our model thus conceptualizes the contingencies for union representatives' boundary-spanning actions. We argue that given their role and existing relationships, union representatives are important actors, leveraging their existing relationships and performing boundary-spanning actions conducive to integration.

We observed how the preexisting relationships were sustained, while the nature of the existing relationships evolved over the integration process. First, the collaborative preexisting intra- and interorganizational relationships were maintained throughout the integration process, reinforced by the boundary-spanning actions. The maintenance of existing relationships thus provided the conduits for continuous boundary-spanning activities throughout the integration process. Second, we observed that as the integration process unfolded, relationships between the union representatives gradually shifted in content and nature. Preacquisition, the plants were competitors, and the union representatives' collaboration was limited to general industrial relations issues and industry-specific concerns. Over time, their collaboration extended to strategic and operational issues, and their shared concerns shifted toward plant and integration issues. In this way, we identified a hybridization of the relationships, where preacquisition competitive interorganizational relationships were recast as new intraorganizational ties that helped coordinate resources and activities between the target and acquiring firms. This shift in nature of interactions reflects the reality of the integration process; as the target and acquiring firms merged, the existing preacquisition interfirm relationships gradually became intrafirm relationships (Ranft \& Lord, 2002).

\section{Discussion}

The initial motivation of our study was the theoretical puzzle of how firms achieve integration to realize value from acquisitions while preventing disruptions to ongoing operations. The surprising empirical observation that union representatives are key actors with existing embedded relationships preacquisition motivated us to focus on their role in the integration process. Pursuing our investigations of the union representatives and their relationships, we found that they leveraged their preexisting embedded inter- and intraorganizational relationships and performed boundary-spanning actions that promoted integration while mitigating conflicts and disruptions. Our findings make several contributions to the postacquisition integration and boundary-spanning literatures.

\section{Contributions to the Postacquisition Integration Literature}

First, we show how a set of actors, mostly ignored by the M\&A literature, can play a key facilitating role in the integration process. Despite their potential role, union representatives are underexplored in the M\&A literature (Davy \& Scheck, 1991). We conceptualize their role as boundary spanners and their preexisting relationships as precursors for their involvement in the integration process. Our findings establish that union representatives may, contingent on their standing in the organization, play an important role in the postacquisition integration process. Previous studies identify managers as key actors in the integration process (Graebner, 2004; Larsson \& Finkelstein, 1999; Teerikangas et al., 2011). Our findings highlight how 
mitigating and mobilizing actions, critical to the integration process, can reside with actors not typically considered constructive to the integration process. We conceptualize the contingencies for, and the mechanisms through which, unexpected actors perform boundaryspanning actions. Our study has implications for our understanding of integration processes as shaped by actors outside the formal hierarchy of the organization. We contend that future research should open up to explore how other unconventional actors may contribute to the dynamics of postacquisition integration.

Second, by theorizing the role of preexisting embedded relationships in the integration process, we contribute to the long-standing dilemma of autonomy versus integration in the M\&A literature. Our findings conceptualize how the maintenance of existing inter- and intraorganizational relationships both increases coordination between firms and mitigates disruptions to ongoing operations. The extant literature posits that the disruption of existing intraorganizational relationships may dilute or even destroy the capabilities that originally motivated the deal, potentially compromising postacquisition capability transfer and value creation (Paruchuri et al., 2006; Puranam et al., 2003). As existing relationships within the organization are dissolved in the postacquisition process (Briscoe \& Tsai, 2011), routines and processes of merging organizations can be undermined (Puranam et al., 2006; Ranft \& Lord, 2002). In contrast, we find that the maintenance of intraorganizational relationships mitigates disruptions to ongoing operations and alleviates the detrimental effects of loss of autonomy. Furthermore, we specify interorganizational relationships as conduits for transfers between the target and acquirer. We add to the recent stream of research adopting a relational perspective on the study of interorganizational encounters (Huang et al., 2016; Z. Lin et al., 2009) more specifically, the study of postacquisition integration (Briscoe \& Tsai, 2011) - by identifying how prevailing preacquisition relationships create conduits for coordination and protect the strategic capabilities of firms.

Third, by highlighting the boundary-spanning and integrative potential in embedded preacquisition relationships, we reveal the benefits and leverage provided by the inertia of relationships in postacquisition integration. Relational inertia may prevent actors from forming new ties postacquisition; as such, organizations need to overcome relational inertia to facilitate integration (Briscoe \& Tsai, 2011). Our findings show that inert relationships may protect strategic capabilities, foster trust, and ease integration, thus allowing a conduit for transfer between organizations. Our findings recast the integration process as facilitated by relational inertia and question the assumption that relational inertia is solely detrimental to integration. Preacquisition relationships can be harnessed and leveraged postacquisition and, thus, form the building blocks for cooperation and coordination in the merged organization. This finding provides M\&A scholars with a previously unspecified integration mechanism to include in future examinations of integration processes.

Finally, previous studies have emphasized postacquisition integration as a unique transitional, hybrid context in which knowledge and capability transfer is not entirely external or internal (Ranft \& Lord, 2002). Our study allows us to specify the dynamics of hybridization of relationships from inter- to intraorganizational. As the integration process unfolds, preexisting, embedded interorganizational relationships are sustained as conduits of coordination and facilitators of social cohesion. As the boundaries between the firms gradually dissolve, the nature and content of these conduits shift. The concept of hybridization allows for a dynamic view of the transition from inter- to intraorganizational coordination inherent in an integration process. 


\section{Contributions to the Boundary-Spanning Literature}

The boundary-spanning literature has extensively addressed the roles of boundary spanners (Ancona \& Caldwell, 1992; Tushman \& Scanlan, 1981), the type of boundary work they perform (Drach-Zahavy \& Somech, 2010), and the consequences of their boundary-spanning activities on organizational performance (Marrone, Tesluk, \& Carson, 2007), but it has remained rather silent on the contingencies of boundary-spanning activities (Calvard, 2014). We extend the boundary-spanning literature by specifying the existence of favorable and embedded inter- and intraorganizational relationships as precursors of boundary spanning. Goal compatibility and trust lay the ground for collaborative relationships between unions and management at the intraorganizational level, while shared interests through union affiliation lay the ground for favorable relationships at the interorganizational level.

The extant literature has focused on the role of boundary spanners in contexts where the boundaries to span are relatively stable, such as between the organization and its environment (Friedman \& Podolny, 1992; Leifer \& Delbecq, 1978), between teams (Ancona \& Cadwell, 1992), and between headquarters and subsidiaries in multinational firms (Birkinshaw et al., 2017; Schotter \& Beamish, 2011). We empirically contribute to this literature by analyzing a transitional organizational context with unstable, changing, and malleable boundaries and where boundary spanners perform actions to facilitate the implementation of organizational change while mitigating the subsequent potential disruptions.

\section{Managerial Implications}

Our findings imply that acquiring firms need to carefully consider unions in the integration process. In organizations where unions have a high standing, union representatives are likely to mitigate the management-employee relationship postacquisition. Union-management relationships governed by goal compatibility foster mobilization and mitigation by union representatives postacquisition. Thus, assessing the quality and the nature of the union-management relationship and the standing of unions preacquisition should be part of integration planning. Furthermore, managers should closely evaluate the involvement of union representatives in the integration process, both pre- and postacquisition.

Our findings have implications beyond union-management relationships. Our findings point to unexpected actors with boundary-spanning capacities and embedded relationships in the integration process. When evaluating organizational fit in the predeal phase, managers should be open to the emergence of key actors with knowledge and informal power and with ties both within and across organizational boundaries. These actors may provide a means for overcoming a potential lack of organizational fit as conduits for knowledge transfer, mitigation, and constructive involvement in the integration process. By involving these actors in the integration process and allowing them space to act, they may provide an untapped resource in the integration process. In postacquisition integration, where management resources are scarce, leveraging resources that contribute to coordination and knowledge sharing can help managers plan and execute the integration process, thereby achieving the strategic goals of the acquisition. 


\section{Boundary Conditions and Future Directions}

Our qualitative research design enables contextualization, vivid description, and an appreciation of subjective views (Lee, 1999; Locke, 2001). It is therefore well suited for the study of complex processes that involve temporal dynamics and that are embedded in nuanced social interactions (Graebner, Martin, \& Roundy, 2012). In interpretative qualitative studies, researchers seek transferability of their findings to other contexts or settings (Lincoln \& Guba, 1985; Miles \& Huberman, 1994). Our findings and contributions are based on a particularly revelatory case, offering an opportunity for transparent and intense observation of a phenomenon (Pettigrew, 1990), as well as the inherent risk that the findings are idiosyncratic.

We examined an organization with a history of collaborative union-management relationships in the metallurgical industry in a Scandinavian institutional setting. In other industries or institutional contexts where unions do not exert power and legitimacy, or in organizations where the union-management relationships are not characterized by trust and collaboration, union representatives may not have the standing or the motivation to contribute constructively in the integration process. Rather, if the union-management relationships are hostile, union representatives' boundary-spanning actions could invoke disruptions and be detrimental to integration. Future research should examine union representatives' boundary-spanning actions in different institutional and organizational contexts.

Our case represents an acquisition with specific characteristics. First, the acquisition was a "friendly" acquisition and perceived as attractive by all parties. It is likely that union representatives may be less amenable to promote acquisitions not perceived as attractive. Rather, they may have an amplifying effect on the integration process, facilitating deals they perceive as attractive while hindering deals they find unattractive. Second, the acquisition was expected to provide synergies from revenue enhancement, cost savings, and knowledge transfer. Future studies could replicate our analysis in acquisition settings that differ in terms of the nature of the deal and scope of the integration process.

Our findings have implications beyond the role of union representatives. We argue that our findings are transferable to contexts where other organizational actors have embedded preexisting relationships. Such actors could be alliance managers in acquisitions of alliance partners, participants in professional associations and alumni networks, and consultants who have embedded relationships allowing them to act as boundary spanners both within and between the firms postacquisition. For example, future studies could explore whether the Council of Medical Professions and the Council of the Bar provide embedded relationships that would facilitate integration in hospital mergers or mergers between law firms.

Our study has implications beyond the postacquisition integration context. Our findings indicate that actors outside the formal hierarchies of the firm, with embedded relationships and boundary-spanning capacities, are key to understanding organizational processes. There are likely other actors with both embedded relationships and boundary-spanning capacities who are normally not considered part of management but who may, given the right circumstances, play managerial roles as exemplified in our case. With a changing industrial landscape that includes increased worker competence, distributed leadership, and collaborative forms of organizing, the boundaries between worker and management roles are dissolving. A broader view of actor roles and relationships may be required to understand and 
effectively navigate these new organizational landscapes. Finally, the hybridization process we identify, with the changing nature of relationships from inter- to intraorganizational in the course of the postacquisition integration process, provides a perspective for understanding organizational relationships and organizational integration in the face of shifting organizational boundaries.

\section{References}

Ancona, D. G., \& Caldwell, D. F. 1992. Bridging the boundary-external activity and performance of organizational teams. Administrative Science Quarterly, 37: 634-665.

Anderson, H., Havila, V., \& Salmi, A. 2001. Can you buy a business relationship? Industrial Marketing Management, 30: 575-586.

Balogun, J., Gleadle, P., Hailey, V. H., \& Willmott, H. 2005. Managing change across boundaries: Boundaryshaking practices. British Journal of Management, 16: 261-278.

Birkinshaw, J., Ambos, T. C., \& Bouquet, C. 2017. Boundary spanning activities of corporate HQ executives. Insights from a longitudinal study. Journal of Management Studies, 54: 422-454.

Briscoe, F., \& Tsai, W. 2011. Overcoming relational inertia: How organizational members respond to acquisition events in a law firm. Administrative Science Quarterly, 56: 408-440.

Bryson, A. 2005. Union effects on employee relations in Britain. Human Relations, 58: 1111-1139.

Burt, R. 1992. Structural holes: The social structure of competition. Cambridge, MA: Harvard University Press.

Calvard, T. S. 2014. Difficulties in organizing boundary-spanning activities of inter-organizational teams. In J. Langan-Fox \& C. L. Cooper (Eds.), Boundary-spanning in organizations: Network, influence, and conflict: 116-142. London: Routledge.

Cappellari, L., Lucifora, C., \& Piccirilli, G. 2004. Union activism, workers' satisfaction and organizational change. Review of Labour Economics \& Industrial Relations, 18: 1-28.

Capron, L. 1999. The long-term performance of horizontal acquisitions. Strategic Management Journal, $20: 987-$ 1018.

Charmaz, K. 2006. Constructing grounded theory: A practical guide through qualitative analysis. London: Sage.

Coffey, A., \& Atkinson, P. 1996. Making sense of qualitative data: Complementary research strategies. London: Sage.

Corley, K. G. 2015. A commentary on "what grounded theory is. .." Engaging a phenomenon from the perspective of those living it. Organizational Research Methods, 18: 600-605.

Cross, R., Nohria, N., \& Parker, A. 2002. Six myths about informal networks-and how to overcome them. MIT Sloan Management Review, 43(3): 67-79.

Datta, D. K. 1991. Organizational fit and acquisition performance: Effects of post-acquisition integration. Strategic Management Journal, 12: 281-297.

Davy, J. A., \& Scheck, C. L. 1991. Are union representatives effective communicators during mergers and takeovers? Labor Studies Journal, 16(3): 3-15.

Drach-Zahavy, A., \& Somech, A. 2010. From an intra-team to an inter-team perspective of effectiveness: The role of interdependence and boundary activities. Small Group Research, 41: 143-174.

Drori, I., Wrzesniewski, A., \& Ellis, S. 2013. One out of many? Boundary negotiation and identity formation in postmerger integration. Organization Science, 24: 1717-1741.

Dubois, A., \& Gadde, L.-E. 2002. Systematic combining: An abductive approach to case research. Journal of Business Research, 55: 553-560.

Eisenhardt, K. M., \& Graebner, M. E. 2007. Theory building from cases: Opportunities and challenges. Academy of Management Journal, 50: 25-32.

Elfenbein, D. W., \& Zenger, T. R. 2014. What is a relationship worth? Repeated exchange and the development and deployment of relational capital. Organization Science, 25: 222-244.

Finkelstein, S., \& Haleblian, J. 2002. Understanding acquisition performance: The role of transfer effects. Organization Science, 13: 36-47.

Friedman, R. A., \& Podolny, J. 1992. Differentiation of boundary spanning roles: Labor negotiations and implications for role conflict. Administrative Science Quarterly, 37: 28-47. 
Gargiulo, M., \& Benassi, M. 2000. Trapped in your own net? Network cohesion, structural holes, and the adaptations of social capital. Organization Science, 11: 183-196.

Gooderham, P. N., Nordhaug, O., \& Ringdal, K. 1999. Institutional and rational determinants of organizational practices: Human resource management in European firms. Administrative Science Quarterly, 44: 507-531.

Graebner, M. E. 2004. Momentum and serendipity: How acquired leaders create value in the integration of technology firms. Strategic Management Journal, 25: 751-777.

Graebner, M. E., Heimeriks, K. H., Huy, Q. N., \& Vaara, E. 2017. The process of postmerger integration: A review and agenda for future research. The Academy of Management Annals, 11: 1-32.

Graebner, M. E., Martin, J. A., \& Roundy, P. T. 2012. Qualitative data: Cooking without a recipe. Strategic Organization, 10: 276-284.

Granovetter, M. 1985. Economic action and social structure: The problem of embeddedness. American Journal of Sociology, 91: 481-510.

Haspeslagh, P. C., \& Jemison, D. B. 1991. Managing acquisitions: Creating value through corporate renewal. New York: Free Press.

Haunschild, P. R. 1993. Interorganizational imitation: The impact of interlocks on corporate acquisition activity. Administrative Science Quarterly, 38: 564-592.

Huang, Y., Luo, Y., Liu, Y., \& Yang, Q. 2016. An investigation of interpersonal ties in interorganizational exchanges in emerging markets: A boundary-spanning perspective. Journal of Management, 42: 1557-1587.

Isbell, M. G. 2012. The role of boundary spanners as the interorganizational link in nonprofit collaborating. Management Communication Quarterly, 26: 159-165.

Jemison, D. B., \& Sitkin, S. 1986. Corporate acquisitions: A process perspective. Academy of Management Review, 11: 145-163.

Kim, T.-H., Oh, H., \& Swaminathan, A. 2006. Framing interorganizational network change: A network inertia perspective. Academy of Management Review, 31: 704-720.

Langley, A. 1999. Strategies for theorizing from process data. Academy of Management Review, 24: 691-710.

Larsson, R., \& Finkelstein, S. 1999. Integrating strategic, organizational and human resources perspectives on mergers and acquisitions: A case survey of synergy realization. Organization Science, 10: 1-26.

Lavelle, J., Gunnigle, P., \& McDonnell, A. 2010. Patterning employee voice in multinational companies. Human Relations, 63: 395-418.

Lee, T. W. 1999. Using qualitative methods to organize research. Newbury Park, CA: Sage.

Leifer, R., \& Delbecq, A. 1978. Organizational/environmental interchange: A model of boundary spanning activity. Academy of Management Review, 3: 40-50.

Lin, L.-H. 2014. Organizational structure and acculturation in acquisitions: Perspectives of congruence theory and task interdependence. Journal of Management, 40: 1831-1856.

Lin, Z., Peng, M. W., Yang, H., \& Sun, S. L. 2009. How do networks and learning drive M\&As? An institutional comparison between China and the United States. Strategic Management Journal, 30: 1113-1132.

Lincoln, Y., \& Guba, E. 1985. Naturalistic inquiry. Beverly Hills, CA: Sage.

Locke, K. 2001. Grounded theory in management research. London: Sage.

Maitlis, S., \& Sonenshein, S. 2010. Sensemaking in crisis and change: Inspiration and insights from Weick (1988). Journal of Management Studies, 47: 551-580.

Marrone, J. A. 2010. Team boundary spanning: A multilevel review of past research and proposals for the future. Journal of Management, 36: 911-940.

Marrone, J. A., Tesluk, P. E., \& Carson, J. B. 2007. A multilevel investigation of antecedents and consequences of team member boundary-spanning behavior. Academy of Management Journal, 50: 1423-1439.

Meznar, M. B., \& Nigh, D. 1995. Buffer or bridge? Environmental and organizational determinants of public affairs activities in American firms. Academy of Management Journal, 38: 975-996.

Miles, M. B., \& Huberman, A. M. 1994. Qualitative data analysis: An expanded sourcebook. Thousand Oaks, CA: Sage.

Mirc, N. 2012. Connecting the micro and macro-level: Proposition of a research design to study post-acquisition synergies through a social network approach. Scandinavian Journal of Management, 28: 121-135.

Öberg, C., \& Holtström, J. 2006. Are mergers and acquisitions contagious? Journal of Business Research, 59: 1267-1275.

Pablo, A. L. 1994. Determinants of acquisition integration level: A decision-making perspective. Academy of Management Journal, 37: 803-836. 
Palmer, D., Xueguang, Z., Barber, B. M., \& Soysal, Y. 1995. The friendly and predatory acquisition of large U.S. corporations in the 1960s: The other contested terrain. American Sociological Review, 60: 469-499.

Paruchuri, S., Nerkar, A., \& Hambrick, D. C. 2006. Acquisition integration and productivity losses in the technical core: Disruption of inventors in acquired companies. Organization Science, 17: 545-562.

Patton, M. Q. 1990. Qualitative evaluation and research methods (2nd ed.). Newbury Park, CA: Sage.

Pettigrew, A. M. 1990. Longitudinal field research on change: Theory and practice. Organization Science, 1: $267-292$.

Porrini, P. 2004. Can a previous alliance between an acquirer and a target affect acquisition performance? Journal of Management, 30: 545-562.

Powell, W. 1990. Neither market nor hierarchy: Network forms of organization. In B. M. Staw \& L. L. Cummings (Eds.), Research in organizational behavior, vol. 12: 295-336. Greenwich, CT: JAI Press.

Puranam, P., Singh, H., \& Zollo, M. 2003. A bird in the hand or two in the bush? Integration trade-offs in technology-grafting acquisitions. European Management Journal, 21: 179-184.

Puranam, P., Singh, H., \& Zollo, M. 2006. Organizing for innovation: Managing the coordination-autonomy dilemma in technology acquisitions. Academy of Management Journal, 49: 263-280.

Ranft, A. L., \& Lord, M. D. 2002. Acquiring new technologies and capabilities: A grounded model of acquisition implementation. Organization Science, 13: 420-441.

Rogan, M., \& Sorenson, O. 2014. Picking a (poor) partner: A relational perspective on acquisitions. Administrative Science Quarterly, 59: 301-329.

Rosenkopf, L., \& Nerkar, A. 2001. Beyond local search: Boundary-spanning, exploration, and impact in the optical disc industry. Strategic Management Journal, 22: 287-306.

Sarala, R. M., Junni, P., Cooper, C. L., \& Tarba, S. Y. 2016. A sociocultural perspective on knowledge transfer in mergers and acquisitions. Journal of Management, 42: 1230-1249.

Schotter, A., \& Beamish, P. W. 2011. Performance effects of MNC headquarters-subsidiary conflict and the role of boundary spanners: The case of headquarter initiative rejection. Journal of International Management, 17: 243-259.

Siggelkow, N. 2007. Persuasion with case studies. Academy of Management Journal, 50: 20-24.

Sleptsov, A., Anand, J., \& Vasudeva, G. 2013. Relational configurations with information intermediaries: The effect of firm-investment bank ties on expected acquisition performance. Strategic Management Journal, 34: 957-977.

Spedale, S., Van Den Bosch, F. A. J., \& Volberda, H. W. 2007. Preservation and dissolution of the target firm's embedded ties in acquisitions. Organization Studies, 28: 1169-1196.

Strand, G. L., \& Skogseid, I. 2013. Management and employees' collaboration: Is the Norwegian work life model suited for all? Systemic Practice and Action Research, 26: 53-74.

Strauss, A. L., \& Corbin, J. 1998. Basics of qualitative research (2nd ed.). Thousand Oaks, CA: Sage.

Teerikangas, S., Véry, P., \& Pisano, V. 2011. Integration managers' value-capturing roles and acquisition performance. Human Resource Management, 50: 651-683.

Tortoriello, M., Reagans, R., \& McEvily, B. 2012. Bridging the knowledge gap: The influence of strong ties, network cohesion, and network range on the transfer of knowledge between organizational units. Organization Science, 23: 1024-1039.

Tushman, M. L., \& Scanlan, T. J. 1981. Boundary spanning individuals: Their role in information transfer and their antecedents. Academy of Management Journal, 24: 289-305.

Uzzi, B. 1996. The sources and consequences of embeddedness for the economic performance of organizations: The network effect. American Sociological Review, 61: 674-698.

Uzzi, B. 1997. Social structure and competition in interfirm networks: The paradox of embeddedness. Administrative Science Quarterly, 42: 35-67.

Van Maanen, J. 1998. Qualitative studies of organizations. Thousand Oaks, CA: Sage.

Wilensky, H. L. 1967. Organizational intelligence: Knowledge and policy in government and industry. New York: Basic Books.

Zaheer, A., Castañer, X., \& Souder, D. 2013. Synergy sources, target autonomy, and integration in acquisitions. Journal of Management, 39: 604-632.

Zollo, M., \& Reuer, J. J. 2010. Experience spillovers across corporate development activities. Organization Science, 21: $1195-1212$

Zollo, M., \& Singh, H. 2004. Deliberate learning in corporate acquisitions: Post-acquisition strategies and integration capability in U.S. bank mergers. Strategic Management Journal, 25: 1233-1256. 